\title{
Moral and social antecedents of young adults' attitudes toward social inequality and social justice values
}

\author{
Tina Malti University of Toronto, Canada \\ tina.malti@utoronto.ca \\ Sebastian P. Dys University of Toronto, Canada \\ Lixian Cui New York University Shanghai, China \\ Marlis Buchmann University of Zurich, Switzerland
}

(Received January $2016 \quad$ Revised September 2016) $\quad$ http://dx.doi.org/10.14301/Ilcs.v8i1.397

\begin{abstract}
In light of growing social stratification, there have been calls to better understand the developmental antecedents of attitudes and values related to social inequality. In this study we predicted attitudes toward social inequality and social justice values from moral and social antecedents in a representative sample of Swiss adolescents $(N=1,258)$ at 15 (Time 1), 18 (Time 2), and 21 years of age (Time 3). We assessed children's sympathy and morals in the context of individuals' decision-making and anticipation of emotions in moral dilemmas. Social-contextual factors included relationship quality, which was assessed by the quality of one's closest friendship and education level. Adolescents who reported higher friendship quality and sympathy showed stronger attitudes toward social inequality later. Interestingly, adolescents' own education level at age 18 positively predicted attitudes toward social inequality at age 21 above and beyond parent education level, but only marginally at a younger age. Social justice values at age 18 were predicted by sympathy and the anticipation of moral emotions at age 15, and social justice values at age 21 were associated with sympathy at age 18. Results are discussed with respect to the potential significance of morality and social-contextual factors in the development of attitudes toward social inequality and social justice values in early adulthood.
\end{abstract}

\section{Keywords}

Attitudes toward social inequality, social justice values, moral development, friendship relationships, longitudinal study 


\section{Introduction}

In light of increasing social and economic stratification across the globe, disciplines across the social sciences have become more interested than ever in issues related to social inequality (Breen \& Jonsson, 2005; Gordon \& Dew-Becker, 2008; Norton \& Ariely, 2011). Though much of this work has examined the impact of social inequalities on outcomes such as educational attainment, income, and health, far less has sought to understand the developmental antecedents of attitudes and values related to these social issues (Killen \& Smetana, 2015; see Daniel, Dys, Buchmann, \& Malti, 2016). Here, we address this gap, in part, by examining attitudes toward inequality, i.e. the degree to which principles of fairness and equality are important to an individual (Rubin, Malti, \& McDonald, 2012) and social justice values, i.e., how much one values justice in the social treatment of individuals (Killen \& Smetana, 2010; Marini, 2000). Attitudes toward inequality and social justice values have been posited as a central outcome of productive development in the third decade of life and an important developmental milestone in young adulthood (Larson, Brown, \& Mortimer, 2002; Lerner, 2004). Both attitudes toward inequality and social justice values are presumed to reflect dimensions of civic competence and factor into the development of social engagement (Lenzi et al., 2014; Rubin, Malti, \& McDonald, 2012; see Brewer, 2003), which may be particularly important for motivating awareness and change around issues of social inequality.

The role of moral and social concepts, such as moral emotions and the quality of close relationships, may yield valuable insight into the formation and development of attitudes toward inequality and social justice values (Flanagan \& Christens, 2011). Yet, few longitudinal studies on the moral and social antecedents of attitudes toward inequality and social justice values have been conducted thus far. The present study addressed this research gap by investigating the moral and social antecedents of attitudes toward inequality and social justice values (for a simplified illustration of the conceptual relations, see figure 1). Here, we highlight important psychological dimension of human functioning: morality. We emphasise the role of young people's morality as it may form the basis for other-oriented concern and as such, may motivate a broadened care for all members of society. Here, we examine both the role of sympathy and the anticipation of selfevaluative moral emotions (e.g. guilt, sadness following wrongdoing; see Malti, 2016) as antecedents of attitudes toward inequality and social justice values. Sympathy, an other-oriented moral emotion, is believed to play a central role in motivating individuals to work toward meeting the needs of others (Eisenberg, 2000). This is because sympathy stems from the apprehension of another's emotional state and is expressed in other-oriented concern, which heightens an individual's attention to the needs of others (Eisenberg, 2000; see Piaget, 1932/1997). Consistent with this notion, there is cross-sectional, longitudinal, and qualitative evidence demonstrating that sympathy is associated with social justice values in adults (Daniel, Dys, Buchmann, \& Malti, 2014; Daniel et al., 2016; Malin, Tirri, \& Liauw, 2015). The anticipation of moral emotions, such as guilt and sadness, in response to hypothetical transgressions reflects the internalisation of moral norms (Malti \& Ongley, 2014). Previous research indicates that individuals often attribute selfevaluative emotions, such as guilt and related feelings of sadness, in such contexts. It has been shown that individuals anticipate such self-evaluative emotions due to the perceived acceptance of internalised norms of fairness and justice and an awareness that one has violated one's own internalised moral principles (Malti, 2016; Malti, Gummerum, Keller, \& Buchmann, 2009; Malti, Keller, \& Buchmann, 2013).

The anticipation of other-oriented and selfevaluative moral emotions, such as sympathy, as well as guilt and sadness following own wrongdoing, has also been empirically linked to prosocial, otheroriented, and fair behaviour (Eisenberg, 2000; Malti \& Krettenauer, 2013). As such, we anticipated that the presence of such emotions, which reflect an internalisation of moral norms and are associated with fair behaviour, may longitudinally predict attitudes toward inequality and social justice values.

In addition, our conceptual model suggests that adolescents' moral and social-emotional development is situated within a broader social space. We propose that an individual's cultural capital and experiences in social, cultural, and economic domains may influence 
their attitudes and values through community involvement (see Verba, Burns, \& Schlozman, 2003). For instance, in the social domain, close relationships act as important basis for social values and can serve as a buffer for risks associated with disengagement and individual maladaptation (Hinde, 1979). The formation of healthy social relationships may also promote the generalisation of other-oriented concerns to broader values. For instance, adolescents who form healthy, secure relations with peers may be more motivated to consider the wellbeing of others (Rubin, Bukowski, \& Laursen, 2009). As broader social concerns become more self-relevant, these experiences may in turn motivate an interest in and commitment to issues of social justice (see Wilkinson, 2010; Wray-Lake \& Syversten, 2011; Yates \& Youniss, 1998).

Furthermore, the model accounts for social inequalities based on cultural capital, such as education. For example, adolescents' education may act as an impetus for social awareness in adolescence and emerging adulthood (Hillygus, 2005; Nie \& Hillygus, 2001). Being aware of the need to act upon principles of fairness, social justice, and equality is likely going to promote the development of social justice values and the motivation to act according to such principles. Meanwhile, parents' education appears to have a multilayered form of influencechildren can directly learn from their parents' attitudes and values, as well as receive indirect influences from their education, for instance, by being able to achieve a higher level of education themselves (Plutzer, 2002; Verba, Burns, \& Scholzman, 2003) or through exposure to broader social networks (Gesthuizen, van der Meer, \& Scheepers, 2008) and civic activities (Bekkers, 2007). Thus, we also examined the effects of adolescents' and parents' levels of education on attitudes toward inequality and social justice values.

Though there has been an increasing interest in the development of attitudes and values related to social inequalities, studies that have investigated both moral and relational factors in their development are sparse. We, therefore, sought to answer the following research questions: First, what is the role of adolescents' moral emotions in the development of attitudes toward inequality and social justice values?
Second, what roles does their relationship quality with close friends play in the development of attitudes toward inequality and social justice values in young adulthood? Based on our conceptual model and the extant evidence, we expected the dimensions of morality to significantly predict subsequent attitudes toward inequality and social justice values. We also hypothesized that the perceived quality of close friendships and parents' and adolescents' levels of education would be associated with later attitudes toward inequality and social justice values. In addition, since adolescent gender has been linked to the development of adolescents' moral emotions and social justice values (e.g., Eisenberg, Zhou, \& Koller, 2001), we controlled for adolescent gender in all multivariate analyses.

\section{Method}

\section{Participants}

Data from the first three waves of the representative ongoing Swiss longitudinal survey COCON (ww.cocon.uzh.ch) were utilised to test our hypotheses. A representative random sample from the German- and French-speaking parts of Switzerland was drawn by a two-stage process in which 131 communities - broken down by community type (i.e., urban, suburban, and rural) and size- were selected. The residents of each community were then randomly sampled on the basis of information provided by the community's official register. Here, we used data from a cohort of adolescents at 15 years of age at Time 1 ( $\mathrm{T} 1, N=1,258,54 \%$ female), 18 years of age at Time $2(T 2, N=952)$, and 21 years of age at Time $3(\mathrm{~T} 3, N=815)$. The adolescents' primary caregivers $(N=1,056)$ also participated at Time 1 .

\section{Procedure}

At the first assessment, in spring 2006, the adolescents were individually interviewed in a quiet room at their home using a computer-assisted personal interview for about 60 minutes. The interview contained questions on the participant's social and moral development. The mothers responded to a questionnaire regarding their adolescent's social and moral development, which was mailed back to the research institute. Both the participant and the primary caregiver supplied written 
informed consent for participation. At the second and third time points (spring 2009 and spring 2012, respectively), a computer-assisted personal interview was conducted with the adolescents and young adults, respectively. The interviewers were recruited from a professional research institute specialising in social sciences, and had been trained extensively by the research team on interview techniques.

\section{Measures}

Attitudes toward inequality. From T1-T3, attitudes toward inequality were assessed using seven items on a six-point Likert scale from 1 (fully disagree) to 6 (fully agree). This measure included items such as "Wealth should be distributed more evenly around the world, even if it requires me to give up some consumer good", "In Switzerland, we spend too much money on welfare, i.e., to support the unemployed and single parents to raise their children" (reverse coded), and "Those who earn well should make a major contribution to the community". The Cronbach's $\alpha$ was .63 at T2 and .65 at T3. At T1, the $\alpha$ coefficient was too low to justify inclusion of the scale into the statistical analyses.

Social justice values. From T1-T3, adolescents' social justice values (Gille, Sardei-Biermann, Gaiser, \& de Rijke, 2006) were reported using a scale that consisted of three items taken from the German Youth Survey. The DJI is a representative, large-scale survey; the social justice value scale has shown to be reliable and valid, both in the German Youth Survey (Gille et al., 2006) and in our pilot study. The scale asked how important it is "To interact with others in a fair way," "To treat all humans equally," and "To minimize inequalities between humans." The answers were rated on a 10-point Likert scale, ranging from 1 (not important at all) to 10 (extremely important). Mean scale scores were computed, with higher scores indicating greater importance of social justice values. Cronbach's $\alpha$ for the value scale was .55 at T1, .70 at $\mathrm{T} 2$, and .63 at $\mathrm{T} 3$.

Sympathy. Sympathy was assessed by self- and caregiver-reports (Zhou, Valiente, \& Eisenberg, 2003). Adolescents reported on their own sympathy from T1-T3. The adolescents' scale consisted of five items from Zhou et al. (2003). A sample item is "When I see another child who is hurt or upset, I feel sorry for him or her." Items were rated using a six-point scale ranging from "not at all like me" to "very much like me." Cronbach's $\alpha$ for the self-reported sympathy scale was .72 at T1, .70 at T2, and .73 at T3.

In addition, at $\mathrm{T} 1$, the mothers rated their children's sympathy on three items from Zhou et al. (2003). A sample item is "My child usually feels sorry for other adolescents who are being teased." Items were rated using a six-point scale ranging from "not at all like my child" to "very much like my child." Cronbach's $\alpha$ for the mother-reported sympathy scale was .78. To create a more robust measure of sympathy for the multivariate analyses, we aggregated adolescent- and caregiver-reports of sympathy, which were significantly correlated, $r=.22, p<.001$.

Moral emotions. Two moral dilemmas were chosen for the current study, involving the choice between well-known moral rules and personal benefit, which closely resembled those experienced in the everyday lives of adolescents in their nature and structure. In the first story, adolescents were read the following: "Imagine you offered your bike for sale. You want to sell it for 500 Swiss Francs. A young man is interested. He bargains with you and you agree on 420 Swiss Francs. Then he says: 'Sorry, I don't have the money on me; I'll quickly run home to get it. I'll be back in half an hour.' You say: 'Agreed, I'll wait for you.' Shortly after he is gone, another customer shows up who is willing to pay the full price." In the second story, the adolescents were read: "Imagine that you have found a purse with 150 Swiss Francs in it and an identity card of the owner." After reading each story, the adolescents were asked what they would do in order to identify their moral evaluations in each situation (moral decision-making), and what they feel thereafter (moral emotions).

To create a score for moral emotions, we coded both responses to dilemmas (moral decision-making and moral emotions) together, such that they created an overt composite score for the anticipation of selfevaluative emotions (for a more detailed description of the coding procedure, see Malti et al., 2013). More specifically, decisions and emotions were combined to create the different patterns of decision-making and emotions (see Malti \& Keller, 2010). The happy victimizer pattern applied to participants who based their decision on selfish reasons and attributed 
positive emotions to the self (for selfish reasons). The unhappy victimizer pattern applied to participants who based their decision on selfish reasons, but who attributed negative emotions to the self for moral reasons. The happy moralist pattern applied to participants who based their decision on moral reasons and attributed positive emotions to the self for moral reasons. The unhappy moralist pattern applied to participants who based their decision on moral reasons, but who felt unhappy due to moral reasons (e.g., empathy for the new customer because he/she is not getting the bike). Participants who opted for the moral decision, but who felt regret due to selfish reasons, were very rare; thus, this pattern was not considered further.

Responses in the unhappy victimizer, happy moralist and unhappy moralist category were coded as "moral emotions occurred" (1), whereas responses in the "happy victimizer" category were coded as "moral emotions did not occur" (0). This was done because the anticipation of emotions in these categories implied an awareness and internalisation of moral norms. Next, to generate a composite score for our measure, we averaged the two scores across both moral dilemmas.

Friendship quality. Perceived friendship quality with a best friend was assessed by self-reports (Parker \& Asher, 1993) from T1-T3 on a 6-point scale, 1 (fully disagree) to 6 (fully agree). This measure consisted of four items such as, "My friend and I trust each other when we give advice," "My friend and I help each other," and "My friend and I discuss what is important in life." Cronbach's $\alpha$ for the scale was .61 at T1, .67 at T2, and .73 at T3.

Parent education. Fathers' and mothers' education levels were reported on a seven-point scale ranging from low to high levels of education (see Malti et al., 2013), i.e., 1 (no education), 2 (compulsory school), 3 (middle school/school section II), 4 (apprenticeship/full time vocational school), 5 (higher technical and vocational training), 6 (higher technical school/college), and 7 (university). A composite score of parent education was created by aggregating father's and mother's education levels for each family. A high score indicates higher levels of parent education.

Adolescent education. At T1, adolescent's education level was reported on a five-point scale (see Malti \& Buchmann, 2010), 1 (without classes/small classes), 2 (section C/junior high school), 3 (section $B+G /$ unarticulated), 4 (section $A+E$, district school), and 5 (high school/secondary school). At T2, adolescent's education level was reported on a fourpoint scale, 1 (no certifying training), 2 (upper secondary education), 3 (training with professional baccalaureate), and 4 (high school). A higher score indicates higher levels of education. The scoring system differed at $\mathrm{T} 1$ and $\mathrm{T} 2$ because at $\mathrm{T} 1$, adolescents were in lower-secondary education (i.e. general education), and at $\mathrm{T} 2$, they were in uppersecondary education, with the majority of young people in VET (vocational training and education) serving an apprenticeship, while the rest being in general education (specialised middle schools or 'Gymnasium').

\section{Analytical Approach}

We first ran descriptive statistics on attitudes toward inequality, social justice values, and all other focal variables, followed by a series of multivariate regression models predicting attitudes toward inequality and social justice values at T2 and T3, respectively using Mplus 7.2 (Muthén \& Muthén, 1998-2012). Adolescent gender was controlled for in all the multivariate analyses.

The retention rates for the current study were $76 \%$ from $\mathrm{T} 1$ to $\mathrm{T} 2$ and $86 \%$ from $\mathrm{T} 2$ to $\mathrm{T} 3$. Missing data analyses of all the models we ran suggested that although the missing patterns were not Missing Completely at Random (MCAR, Little, 1988), the missingness was predicted by the variables included in the model, such that adolescents with lower morality, and education level were more likely to be missing on attitudes toward inequality and social justice values at both T2 and T3. Therefore, Missing at Random (MAR) was assumed and the maximum likelihood with robust error (MLR) was used for parameter estimation in all analyses to account for missing values in Mplus 7.2 (Muthén \& Muthén, 1998-2012).

\section{Results}

\section{Descriptive statistics}

Table 1 displays the means and standard 
deviations of all continuous study variables by assessment point. As shown in table 2, attitudes toward inequality at T2 and T3 were associated with most independent variables at both $\mathrm{T} 1$ and $\mathrm{T} 2$. Similarly, social justice values at T1-T3 were related to most independent variables in the expected direction but not significantly associated with parent and adolescent education levels.

\section{Prediction of attitudes toward inequality and social justice values by moral emotions and social factors}

To test how moral development and social factors predicted attitudes toward inequality and social justice values at both $\mathrm{T} 2$ and $\mathrm{T} 3$, we ran linear regression analyses using $\mathrm{T} 1$ independent variables to predict $\mathrm{T} 2$ attitudes toward inequality and social justice values, and using $\mathrm{T} 2$ independent variables to predict T3 attitudes toward inequality and social justice values, respectively (see table 3 ). These two variables were treated separately because they are conceptualised as distinct constructs. However, we predicted them in the same model in a multivariate way. We found that T1 perceived friendship quality, T1 sympathy (self- and parent-reports combined), and parent education level significantly predicted T2 attitudes toward inequality (table 3 ). We also found that T1 sympathy (self- and parent-reports combined) and T1 moral emotions significantly predicted T2 social justice values, after controlling for T1 social justice values. The correlation between attitudes toward inequality and social justice values at $\mathrm{T} 2$ was in the medium range, $r=.41, p<.001$. Total variances explained by the independent variables were $11 \%$ for attitudes toward inequality and $12 \%$ for social justice values.

Next, we predicted attitudes toward inequality and social justice values at T3 using T2 independent variables. The findings showed significant effect of $\mathrm{T} 2$ sympathy (self-reports), as well as T2 adolescent education levels and parent education levels in predicting T3 attitudes toward inequality, after controlling for $\mathrm{T} 2$ attitudes toward inequality. For the prediction of T3 social justice values, T2 sympathy showed a significant effect, after controlling for T2 social justice values. As expected, attitudes toward inequality and social justice values at T3 were significantly correlated in a small range, $r=.28, p<$ .001 . Total variances explained by the independent variables were $26 \%$ for attitudes toward inequality and $27 \%$ for social justice values.

\section{Discussion}

One of the major challenges during the transition into adulthood involves engaging in, and committing to, democratic principles of justice and fairness (Flanagan \& Gallay, 1995). Our study aimed at investigating central moral-developmental and social antecedents of attitudes toward inequality and social justice values. In particular, we focused on the influence of moral emotions, friendship quality, and socioeconomic status in predicting these attitudes and values.

Our findings suggest that moral emotions, i.e. sympathy, play a central role in the subsequent development of attitudes toward inequality and social justice values. This is in line with previous studies highlighting the role of sympathy in promoting related outcomes, such as prosocial orientations and behaviours (Eisenberg, Spinrad, \& Knafo-Noam, 2015). Similarly, the findings support the notion that individuals who feel concern for the distress of victims of injustice are more likely to feel committed to such principles (Hoffman, 2000). Moreover, this is consistent with, and extends previous studies documenting a longitudinal link between sympathy and social justice values trajectories (e.g. Daniel et al., 2014). There was also some support for the role of self-evaluative moral emotions at T1 on subsequent social justice values. This may support the idea that self-evaluative moral emotions may function to promote other-oriented behaviour and values by evoking unpleasant feelings in response to violating one's personal moral code (see Carlo, McGinley, Davis, \& Streit, 2012; Ongley \& Malti, 2014). In short, it appears that young adults' moral sentiments may promote a sense for inequality and related values of social justice (Montada \& Schneider, 1989; see van Goethem et al., 2012).

In line with our developmental-relational model, we also found some support for the role of friendship quality in subsequent attitudes toward inequality, which resonates with theorizing (Lewis, MacGregor, \& Putnam, 2013) and US longitudinal research (Obradovic \& Masten, 2007). Positive experiences in close friendships may help young 
people appreciate the need for social cohesion and interpersonal responsibility, and experience advancing these causes as meaningful and satisfying. Moreover, high quality friendships are likely to be indicative of other social competencies (not directly measured here), which are central to attitudes toward justice and equality. For instance, active listening and perspective-taking are often applied to achieve social understanding and unity (Flanagan \& Faison, 2001; Obradovic \& Masten, 2007). By providing concrete opportunities to connect with the needs and perspectives of others, close friendships may stimulate adolescents' concern for social equality.

Consistent with previous literature (e.g., Verba et al., 2003), we found parental education to predict attitudes toward inequality. Interestingly, adolescents' education at T2 also predicted attitudes toward inequality at $\mathrm{T} 3$, beyond the influence of parents' education. One potential reason is that educational programming in late adolescence may be much better at helping young people understand how society operates, and how they can influence that operation (see Hillygus, 2005). Alternatively, adolescents may not develop extensive social networks of their own until their twenties, resulting in a more pronounced effect of their parents' social networks on adolescents' attitudes toward inequality at an earlier age (see Gesthuizen et al., 2008). Thus, consistent with our model, it appears that early social experiences and differences in educational attainment may colour young peoples' perceptions and expectations of social interactions and society, and in so doing influence their degree of concern for broader social issues.

While the present study addresses an important void in research on attitudes toward inequality and social justice values in adulthood, it is not without its limitations. First, due to the large-scale approach to our data collection, our measure of social justice values was limited to three items and as such relied on relatively simple general statements. However, this measure has been employed and validated in previous large-scale studies (Gille et al., 2006). Second, many of our measures relied on selfreports, which may be susceptible to social desirability. Still, self-reports are necessary and invaluable for the study of morality and values, as these are typically challenging to measure through other informants or behavioural measures. Moreover, while social desirability biases tend to positively relate to valuing harmony, they are unrelated to universalism values (e.g. social justice values; Schwartz, Verkasalo, Antonovsky, \& Sagiv, 1997). Third, the validity of our measures was somewhat limited by the internal consistency of our measures. Although some of our measures (e.g. social justice values, friendship quality) had, at times, relatively low reliability coefficients, they are still considered acceptable as lower scores are typical of scales with few items (Schmitt, 1996). Given that one of our scales, attitudes toward inequality, had low reliability at the first assessment point, we were unable to control for it in the longitudinal prediction of outcomes. Future studies are therefore warranted to replicate finding when controlling for Time 1 attitudes toward inequality.

Despite these limitations, the present study provides a valuable contribution to our understanding of attitudes and social values in the third decade. To conclude, we aimed, in part, to address the need for research connecting social and moral concepts in adolescence to attitudes toward inequality and social justice values in early adulthood (Killen \& Smetana, 2010). Both moral and social factors in adolescence were longitudinally predictive of attitudes toward injustice and social justice values. Taken together, these findings support the view that both moral emotions and close relationships are likely to impact young adults' attitudes and social values. 


\section{Acknowledgments}

This research was supported with grants from the Swiss National Science Foundation, Jacobs Foundation, and the University of Zurich to Marlis Buchmann. Sebastian Dys was supported with a scholarship from the Natural Sciences and Engineering Research Council of Canada.

\section{References}

Bekkers, R. (2007). Intergenerational transmission of volunteering. Acta Sociologica, 50(2), 99-114. https://doi.org/10.1177/0001699307077653

Breen, R., \& Jonsson, J. O. (2005). Inequality of opportunity in comparative perspective: Recent research on educational attainment and social mobility. Annual Review of Sociology, 31, 225-243. https://doi.org/10.1146/annurev.soc.31.041304.122232

Brewer, G.A. (2003). Building social capital: Civic attitudes and behavior of public servants. Journal of Public Administration Research and Theory, 13(1), 5-26. https://doi.org/10.1093/jopart/mug011

Carlo, G., McGinley, M., Davis, A., \& Streit, C. (2012). Behaving badly or goodly: Is it because I feel guilty, shameful, or sympathetic? Or is it a matter of what I think? New Directions for Youth Development, 136, 75-93. https://doi.org/10.1002/yd.20040

Daniel, E., Dys, S.P., Buchmann, M., \& Malti, T. (2014). Developmental relations between sympathy, moral emotion attributions, moral reasoning, and social justice values from childhood to early adolescence. Journal of Adolescence, 37(7), 1201-1214. https://doi.org/10.1016/j.adolescence.2014.08.009

Daniel, E., Dys, S.P., Buchmann, M., \& Malti, T. (2016). Developmental trajectories of social justice values in adolescence: Relations with sympathy and friendship quality. Social Development, 25, 548-564. https://doi.org/10.1111/sode.12146

Eisenberg, N. (2000). Emotion, regulation, and moral development. Annual Review of Psychology, 51, 665-697. https://doi.org/10.1146/annurev.psych.51.1.665

Eisenberg, N., Spinrad, T.L., \& Knafo-Noam, A. (2015). Prosocial development. In M. E. Lamb (Vol. Ed.) and R.M. Lerner (Series Ed.), Handbook of child psychology and developmental science, Vol. 3: Social, emotional and personality development (7th edition, pp. 610-656). New York: Wiley. https://doi.org/10.1002/9781118963418.childpsy315

Eisenberg, N., Zhou, Q., \& Koller, S. (2001). Brazilian adolescents' prosocial moral judgment and behavior: relations to sympathy, perspective taking, gender-role orientation, and demographic characteristics. Child Development, 72, 518-534. https://doi.org/10.1111/1467-8624.00294

Flanagan, C. A., \& Faison, N. (2001). Youth civic development: Implications of research for social policy and programs. Social Policy Report, Vol. XV (1). Ann Arbor, MI: Society for Research in Child Development.

Flanagan, C. A. \& Gallay, L. S. (1995). Reframing the meaning of "political" in research with adolescents. Perspectives on Political Science, 24, 34-41. https://doi.org/10.1080/10457097.1995.9941863

Flanagan, C. A., Levine, P. (2010). Civic engagement and the transition to adulthood. The Future of Children, 20(1), 159-179. https://doi.org/10.1353/foc. 0.0043

Gesthuizen, M., van der Meer, T., \& Scheepers, P. (2008). Education and dimensions of social capital: Do educational effects differ due to educational expansion and social security expenditure? European Sociological Review, 24(5), 617-632. https://doi.org/10.1093/esr/jcn021

Gille, M., Sardei-Biermann, S., Gaiser, W., \& de Rijke, J. (2006). Jugendliche und junge Erwachsene in Deutschland [adolescents and young adults in Germany]. Wiesbaden, Germany: Verlag fuer Sozialwissenschaften.

Gordon, R. J., \& Dew-Becker, I. (2008). Controversies about the rise of American inequality: A survey. NBER Working Papers 13982, National Bureau of Economic Research. https://doi.org/10.3386/w13982

Hillygus, S. (2005). The Missing Link: Exploring the relationship between higher education and political engagement. Political Behavior 27(1), 25-47. https://doi.org/10.1007/s11109-005-3075-8 
Hinde, R. A. (1979). Towards understanding relationships. London: Academic Press.

Hitlin, S., \& Vaisey, S. (2013). The new sociology of morality. Annual Reviews of Sociology, 39, 51-68. https://doi.org/10.1146/annurev-soc-071312-145628

Hoffman, M. L. (2000). Empathy and moral development: Implications for caring and justice. New York: Cambridge University Press. https://doi.org/10.1017/CBO9780511805851

Killen, M., \& Smetana, J. G. (2010). Future directions: social development in the context of social justice. Social Development, 19(3), 642-657. https://doi.org/10.1111/j.1467-9507.2009.00548.x

Killen, M., \& Smetana, J.G. (2015). Origins and development of morality. In M. E. Lamb (Ed.), Handbook of child psychology and developmental science, Vol. 3, 7th edition (pp. 701-749). Editor-in-Chief, R. M. Lerner. NY: Wiley-Blackwell. https://doi.org/10.1002/9781118963418.childpsy317

Jennings, M. K., \& Stoker, L. (2004). Social trust and civic engagement across time and generations. Acta Politica, 39(4), 342-379. https://doi.org/10.1057/palgrave.ap.5500077

Larson, R., Brown, B. B., \& Mortimer, J. (2002). Adolescents' preparation for the future: Perils and promise. Journal of Research on Adolescence, 12, 1-166. https://doi.org/10.1111/1532-7795.00023

Lenzi, M., Vieno, A., Sharkley, J., Mayworm, A., Scacchi, L., Pastore, M., \& Santinello, M. (2014). How school can teach civic engagement besides civic education: The role of democratic school climate. American Journal of Community Psychology, 54(3), 251-261. https://doi.org/10.1007/s10464-014-9669-8

Lerner, R. (2004). Liberty: Thriving and civic engagement among America's youth. Thousand Oaks, CA: Sage.

Lewis, V. A., MacGregor, C. A., Putnam, R. D. (2013). Religion, networks, and neighborliness: The impact of religious social networks on civic engagement. Social Science Research, 42(2), 331-346. https://doi.org/10.1016/j.ssresearch.2012.09.011

Little, R. J. A. (1988). A test of missing completely at random for multivariate data with missing values. Journal of the American Statistical Association, 83, 1198-1202. https://doi.org/10.1080/01621459.1988.10478722

Malti, T. (2016). Toward an integrated clinical-developmental model of guilt. Developmental Review, 39, 16-36. https://doi.org/10.1016/i.dr.2015.11.001

Malti, T., \& Buchmann, M. (2010). Socialization and individual antecedents of adolescents' and young adults' moral motivation. Journal of Youth and Adolescence, 39(2), 138-149. https://doi.org/10.1007/s10964009-9400-5

Malti, T., Gummerum, M., Keller, M., \& Buchmann, M. (2009). Children's moral motivation, sympathy, and prosocial behavior. Child Development, 80, 442-460. https://doi.org/10.1111/j.1467-8624.2009.01271.x

Malti, T., \& Keller, M. (2010). Development of moral emotions in cultural context. In W. Arsenio \& E. Lemerise (Eds.), Emotions, aggression, and morality in children: Bridging development and psychopathology (pp. 177-198). Washington, DC: American Psychological Association. https://doi.org/10.1037/12129-009

Malti, T., Keller, M., \& Buchmann, M. (2013). Do moral choices make us feel good? The development of adolescent's emotions following moral decision-making. Journal of Research on Adolescence, 23(2), 389-397. https://doi.org/10.1111/jora.12005

Malti, T., \& Krettenauer, T. (2013). The relation of moral emotion attributions to prosocial and antisocial behavior: A meta-analysis. Child Development, 84(2), 397-412. https://doi.org/10.1111/j.14678624.2012.01851.x

Malti, T., \& Ongley, S. F. (2014). The development of moral emotions and moral reasoning. In M. Killen \& J. Smetana (Eds.), Handbook of moral development ( $2^{\text {nd }}$ edition) (pp. 163-183). New York: Psychology Press. https://doi.org/10.4324/9780203581957.ch8

Marini, M. M. (2000). Social values and norms. In E. F. Borgatta, \& R. J. V. Montgomery (Eds.), Encyclopedia of sociology (2nd ed., pp. 2828-2840). Detroit: Macmillan Reference.

Montada, L., \& Schneider, A. (1989). Justice and emotional reactions to the disadvantaged. Social Justice Research, 3(4), 313-344. https://doi.org/10.1007/BF01048081 
Muthén, L. K., \& Muthén, B. O. (1998-2012). Mplus User's Guide. Seventh Edition. Los Angeles, CA: Muthén \& Muthén.

Norton, M. I., \& Ariely, D. (2011). Building a better America-One wealth quintile at a time. Psychological Science, 6, 9-12. https://doi.org/10.1177/1745691610393524

Nie, N. H., \& Hillygus, D.S. (2001). Education and Democratic Citizenship: Explorations into the Effects of What Happens in the Pursuit of the Baccalaureate. In Education and Civil Society, by D. Ravitch \& J. Viteritti (Eds.). New Haven, CT: Yale University Press.

Obradovic, J., \& Masten, A. S. (2007). Developmental antecedents of young adult civic engagement. Applied Developmental Science, 11, 2-19. https://doi.org/10.1207/s1532480xads1101 1

Ongley, S. F., \& Malti, T. (2014). The role of moral emotions in the development of children's sharing behavior. Developmental Psychology, 50(4), 1148-1159. https://doi.org/10.1037/a0035191

Parker, J. G., \& Asher, S. R. (1993). Friendship and friendship quality in middle childhood: Links with peer group acceptance and feelings of loneliness and social dissatisfaction. Developmental Psychology, 29, 611621. https://doi.org/10.1037/0012-1649.29.4.611

Piaget J. (1997). The Moral Judgment of the Child. New York: The Free Press (Original work published 1932).

Plutzer, E. (2002). Becoming a habitual voter: Inertia, resources, and growth in young adulthood. American Political Science Review, 96(1), 41-56. https://doi.org/10.1017/S0003055402004227

Putnam, R. D. (2000). Bowling alone: The collapse and revival of American community. New York: Simon \& Schuster. https://doi.org/10.1145/358916.361990

Rubin, K. H., Bukowski , W., \& Laursen, B. (Eds.) (2009), Handbook of peer interactions, relationships, and groups. New York: Guilford.

Rubin, K. H., Malti, T., \& McDonald, K. L. (2012). Civic development in relational perspective. In G. Trommsdorff \& X. Chen (Eds.), Values, religion, and culture in adolescent development (pp. 188-208). Cambridge: Cambridge University Press. https://doi.org/10.1017/CB09781139013659.011

Schmitt, N. (1996). Uses and abuses of coefficient alpha. Psychological Assessment, 8(4), 350-353. https://doi.org/10.1037/1040-3590.8.4.350

Schwartz, S. H., Verkasalo, M., Antonovsky, A., \& Sagiv, L. (1997). Value priorities and social desirability: Much substance, some style. British Journal of Social Psychology, 36(1), 3-18. https://doi.org/10.1111/i.20448309.1997.tb01115.x

van Goethem, A. A. J., van Hoof, A., van Aken, M. A. G., Raaijmakers, A. W., Boom, J., \& de Castro, B. O., (2012). The role of adolescents' morality and identity in volunteering. Age and gender differences in a process model. Journal of Adolescence, 35, 509-520. https://doi.org/10.1016/j.adolescence.2011.08.012

Verba, S., Burns, N., \& Scholzman, K. L. (2003). Unequal at the starting line: Creating participatory inequalities across generations and among groups. The American Sociologist, 34(1-2), 45-69. https://doi.org/10.1007/s12108-003-1005-y

Wilkinson, J. (2010). Personal communities: Responsible individualism or another fall for public [man]? Sociology, 44(4), 453-470. https://doi.org/10.1177/0038038510362484

Wray-Lake, L., \& Syvertsen, A. K. (2011). The developmental roots of social responsibility in childhood and adolescence. New Directions for Child and Adolescent Development, 134, 11-25. https://doi.org/10.1002/cd.308

Youniss, J., \& Yates, M. (1999). Youth service and moral-civic identity: A case for everyday morality. Educational Psychology Review, 11(4), 361-376. https://doi.org/10.1023/A:1022009400250

Zhou, Q., Valiente, C., \& Eisenberg, N. (2003). Empathy and its measurement. In S. J. Lopez, \& C. R. Snyder (Eds.), Positive psychological assessment: A handbook of models and measures (pp. 269-284). Washington, DC, US: American Psychological Association. https://doi.org/10.1037/10612-017 
Table 1. Means and standard deviations of the main study variable by assessment point

\begin{tabular}{|c|c|c|c|c|c|c|c|c|c|c|}
\hline \multirow[t]{2}{*}{ s } & \multirow[b]{2}{*}{ Range } & \multicolumn{3}{|c|}{$\mathrm{T} 1$} & \multicolumn{3}{|c|}{$\mathrm{T} 2$} & \multicolumn{3}{|c|}{ T3 } \\
\hline & & $N$ & Mean & $S D$ & $N$ & Mean & $S D$ & $N$ & Mean & $S D$ \\
\hline Attitudes toward inequality & $1-6$ & $--^{a}$ & $--^{a}$ & $--^{a}$ & 952 & 4.79 & 0.62 & 814 & 4.80 & 0.61 \\
\hline Social justice values & $1-10$ & 1257 & 8.66 & 1.17 & 952 & 8.69 & 1.18 & 815 & 8.65 & 1.09 \\
\hline Parent education & $1-7$ & 1241 & 4.16 & 1.28 & $--^{b}$ & $---b$ & $--b$ & $--b$ & $--^{b}$ & $--b$ \\
\hline Adolescent education & $1-5$ & 1245 & 3.32 & 1.01 & 950 & 3.63 & 1.00 & $--b$ & $--^{b}$ & $--b$ \\
\hline Friendship quality & $1-6$ & 1255 & 5.42 & 0.69 & 946 & 5.69 & 0.40 & 811 & 5.70 & 0.43 \\
\hline Sympathy (S) & $1-6$ & 1257 & 4.81 & 0.76 & 952 & 4.81 & 0.72 & 815 & 4.84 & 0.70 \\
\hline Sympathy (P) & $1-6$ & 1048 & 4.92 & 0.95 & $--b$ & $--b$ & $--b$ & $--b$ & $--b$ & $--b$ \\
\hline Moral emotions & $0-1$ & 1227 & 0.81 & 0.26 & 929 & 0.84 & 0.27 & 743 & 0.89 & 0.22 \\
\hline
\end{tabular}




\section{Table 2. Bivariate correlations between study variables}

\begin{tabular}{|c|c|c|c|c|c|c|c|c|c|c|}
\hline & 1 & 2 & 3 & 4 & 5 & 6 & 7 & 8 & 9 & 10 \\
\hline 1. Attitudes toward inequality $\mathrm{T3}$ & -- & & & & & & & & & \\
\hline 2. Attitudes toward inequality $\mathrm{T} 2$ & $.50^{* * *}$ & -- & & & & & & & & \\
\hline 3. Social justice values T3 & $.41^{* * *}$ & $.35^{* * *}$ & -- & & & & & & & \\
\hline 4. Social justice values T2 & $.30^{* * *}$ & $.45^{* * *}$ & $.52^{* * *}$ & -- & & & & & & \\
\hline 5. Social justice values T1 & $.17^{* * *}$ & $.23^{* * *}$ & $.28^{* * *}$ & $.29^{* * *}$ & -- & & & & & \\
\hline 6. Gender & $-.10^{* *}$ & $-.13^{* * *}$ & $-.22^{* * *}$ & $-.24^{* * *}$ & $-.22^{* * *}$ & -- & & & & \\
\hline 7. Parent education & $.15^{* * *}$ & $.11^{* *}$ & -.06 & -.06 & .02 & $.06^{*}$ & -- & & & \\
\hline 8. Adolescent education T2 & $.20^{* * *}$ & $.11^{* *}$ & .01 & -.02 & $.12^{* * *}$ & -.03 & $.30^{* * *}$ & -- & & \\
\hline 9. Adolescent education T1 & $.16^{* * *}$ & $.13^{* * *}$ & -.02 & -.04 & $.07^{*}$ & $-.06^{*}$ & $.34^{* * *}$ & $.57^{* * *}$ & -- & \\
\hline 10. Friendship quality T2 & $.10^{* *}$ & $.20^{* * *}$ & $.19^{* * *}$ & $.25^{* * *}$ & $.10^{* *}$ & $-.23^{* * *}$ & -.05 & .001 & .03 & -- \\
\hline 11. Friendship quality $\mathrm{T} 1$ & .04 & $.14^{* * *}$ & $.12^{* *}$ & $.18^{* * *}$ & $.22^{* * *}$ & $-.41^{* * *}$ & -.06 & -.06 & -.01 & $.34^{* * *}$ \\
\hline 12. Sympathy (S) T2 & $.28^{* * *}$ & $.40^{* * *}$ & $.31^{* * *}$ & $.36^{* * *}$ & $.21^{* * *}$ & $-.24^{* * *}$ & .02 & .02 & .06 & $.24^{* * *}$ \\
\hline 13. Sympathy (S) T1 & $.18^{* * *}$ & $.25^{* * *}$ & $.23^{* * *}$ & $.24^{* * *}$ & $.40^{* * *}$ & $-.26^{* * *}$ & -.02 & .06 & .05 & $.15^{* * *}$ \\
\hline 14. Sympathy (P) T1 & $.15^{* * *}$ & $.21^{* * *}$ & $.18^{* * *}$ & $.16^{* * *}$ & $.19^{* * *}$ & $-.20^{* * *}$ & .01 & .06 & .06 & $.08^{*}$ \\
\hline 15. Moral emotions T2 & $.14^{* * *}$ & $.18^{* * *}$ & $.18^{* * *}$ & $.19^{* * *}$ & $.14^{* * *}$ & $-.17^{* * *}$ & .02 & $.07^{*}$ & $.07^{*}$ & $.11^{* *}$ \\
\hline 16. Moral emotions T1 & .05 & $.12^{* * *}$ & .06 & $.15^{* * *}$ & $.13^{* * *}$ & $-.12^{* * *}$ & .01 & .04 & .02 & $.07^{*}$ \\
\hline
\end{tabular}




\section{Table 2 (Con't)}

\begin{tabular}{lccccc}
\hline & 11 & 12 & 13 & 14 & 15 \\
\hline 11. Friendship quality T1 & -- & & & & \\
12. Sympathy (S) T2 & $.17^{* * *}$ & -- & & & \\
13. Sympathy (S) T1 & $.30^{* * *}$ & $.41^{* * *}$ & -- & & \\
14. Sympathy (P) T1 & $.12^{* * *}$ & $.19^{* * *}$ & $.22^{* * *}$ & -- & \\
15. Moral emotions T2 & $.10^{* *}$ & $.22^{* * *}$ & $.14^{* * *}$ & $.16^{* * *}$ & -- \\
16. Moral emotions T1 & .04 & $.18^{* * *}$ & $.19^{* * *}$ & $.17^{* * *}$ & $.27^{* * *}$
\end{tabular}

Note. Gender: female = 0, male $=1 . \mathrm{S}=$ Self-report; $\mathrm{P}=$ Parent-report. $\mathrm{T} 1=$ Time $1 . \mathrm{T} 2=$ Time $2 . \mathrm{T} 3=$ Time 3.

${ }^{*} p<.05$. $^{* *} p<.01$. $^{* * *} p<.001$. 
Table 3. Multivariate regression analyses predicting attitudes toward Inequality and social justice values at T2 and T3

\begin{tabular}{|c|c|c|c|c|c|c|c|}
\hline \multirow[t]{2}{*}{ Model 1} & \multicolumn{3}{|c|}{ Attitudes Toward Inequality T2 } & & \multicolumn{3}{|c|}{ Social Justice Values T2 } \\
\hline & $\beta$ & $S E$ & $R^{2}$ & & $\beta$ & SE & $R^{2}$ \\
\hline & -- & -- & & Social justice values T1 & $0.15^{* * *}$ & 0.04 & \\
\hline Gender & -0.02 & 0.03 & & Gender & $-0.13^{* * *}$ & 0.03 & \\
\hline Parent education & $0.10^{* *}$ & 0.03 & & Parent education & -0.03 & 0.03 & \\
\hline Adolescent education T1 & $0.06^{+}$ & 0.03 & & Adolescent education T1 & $-0.06^{\dagger}$ & 0.03 & \\
\hline Friendship quality T1 & $0.07^{*}$ & 0.03 & & Friendship quality T1 & 0.05 & 0.04 & \\
\hline Sympathy (S\&P) T1 & $0.24^{* * *}$ & 0.03 & & Sympathy (S\&P) T1 & $0.14^{* * *}$ & 0.04 & \\
\hline Moral emotions T1 & 0.04 & 0.04 & & Moral emotions T1 & $0.08^{*}$ & 0.04 & \\
\hline Total $R^{2}$ & & & $.11^{* * *}$ & Total $R^{2}$ & & & $.12^{* * *}$ \\
\hline$N$ & & & 922 & $N$ & & & 922 \\
\hline \multirow[t]{2}{*}{ Model 2} & \multicolumn{3}{|c|}{ Attitudes Toward Inequality T3 } & & \multicolumn{3}{|c|}{ Social Justice Values T3 } \\
\hline & $\beta$ & $S E$ & $R^{2}$ & & $\beta$ & $S E$ & $R^{2}$ \\
\hline Attitudes toward Inequality T2 & $0.41^{* * *}$ & 0.04 & & Social justice values T2 & $0.39^{* * *}$ & 0.05 & \\
\hline Gender & -0.02 & 0.03 & & Gender & $-0.07^{*}$ & 0.03 & \\
\hline Parent education & $0.10^{* *}$ & 0.04 & & Parent education & -0.03 & 0.04 & \\
\hline Adolescent education T2 & $0.09^{*}$ & 0.04 & & Adolescent education T2 & -0.02 & 0.04 & \\
\hline Friendship quality T2 & 0.04 & 0.04 & & Friendship quality T2 & 0.05 & 0.04 & \\
\hline Sympathy (S) T2 & $0.09^{*}$ & 0.04 & & Sympathy (S) T2 & $0.14^{* * *}$ & 0.04 & \\
\hline Moral emotions T2 & 0.03 & 0.04 & & Moral emotions T2 & $0.07^{\dagger}$ & 0.04 & \\
\hline Total $R^{2}$ & & & $.26^{* * *}$ & Total $R^{2}$ & & & $.27^{* * *}$ \\
\hline$N$ & & & 766 & $N$ & & & 766 \\
\hline
\end{tabular}

Note. Gender: female $=0$, male $=1 . \quad \mathrm{S}=$ Self-report; S\&P $=$ Self- and parent-reports combined; $\mathrm{T} 1=$ Time $1 . \mathrm{T} 2=\mathrm{Time} 2 . \mathrm{T} 3=\mathrm{Time}$ 3. ${ }^{\dagger} p<.10 .{ }^{*} p<.05 .{ }^{* *} p<.01 .^{* * *} p<.001$. 




Note: Italicized dimensions of constructs are the focus of the present study.

Figure 1. Simplified conceptual model of attitudes toward social inequality and social justice values and their moral and socialcontextual antecedents. 